\title{
Pharmacognostic, Phytochemical and In vitro Biological Evaluation of Blepharis repens (Vahl) Roth
}

\author{
Sharada L. Deore*, Poonam B. Bhansali, Bhushan A. Baviskar
}

Sharada L. Deore*, Poonam B. Bhansali, Bhushan A. Baviskar

Department of Pharmacognosy and Phytochemistry, Government College of Pharmacy, Kathora naka, Amravati (Maharashtra) 444604, INDIA.

\section{Correspondence}

\section{Sharada L. Deore}

Department of Pharmacognosy and Phytochemistry, Government College of Pharmacy, Kathora naka, Amravati (Maharashtra) 444604, INDIA.

E-mail: sharudeore_2@yahoo.com

History

- Submission Date: 15-04-2020;

- Review completed: 05-05-2020;

- Accepted Date: 08-05-2020.

DOI : 10.5530/pj.2020.12.135

Article Available online

http://www.phcogj.com/v12/i5

Copyright

(C) 2020 Phcogj.Com. This is an openaccess article distributed under the terms of the Creative Commons Attribution 4.0 International license.

\section{ABSTRACT}

Blepharis repens (Vahl) Roth of Acanthaceae family, commonly known as Hadsan in Marathi and Haridachchu in Kannada, is threatened species due to exploitation from natural habitat. Objectives: The objective of present study is to establish scientifically well evaluated pharmacognostic and biological efficacy parameters. Methods: Microscopical parameters of leaf, root and stem are evaluated. Powder microscopy, physicochemical analysis, elemental analysis, fluorescence analysis, preliminary phytochemical screening and estimation of major phytoconstituents of whole herb powder are carried out. In vitro biological evaluation of Blepharisrepens carried out for antioxidant potential by DPPH method, in vitro anticancer activity by SRB assay and antimicrobial efficacy by both agar well diffusion and bioautography methods. Results: Morphologically, roots are cylindrical and elongated, leaf has symmetric base, entire margin, acute apex while stem is cylindrical, elongated. Microscopic evaluation reveals that both leaf and stem are covered with trichomes. Leaf has unicellular uniseriate trichomes while stem has multi-cellular uniseriate covering trichomes. Physicochemical evaluation revealed that total ash, acid insoluble ash and water-soluble ash values 13.857 .7 and $3.1 \%$ respectively. Petroleum ether, alcohol and water extractive values found $0.84 \%, 1.64 \%$, and $3.52 \%$ respectively. Loss on drying value is found $3.43 \%$. Element analysis of whole herb confirms presence of nitrogen, sulphate and carbonate. Fluorescence tests are performed by treatment with different acids and alkalis and exposure to ultraviolet light. Phytochemical screening shows presence of carbohydrates, alkaloids, tannins, flavonoids and saponins. Estimation of phytochemicals like carbohydrate, alkaloid, tannin and flavonoid found $5.78 \%$, $1.43 \%, 5.7 \%$ and $1.48 \%$ respectively. Biological evaluation reveals that plant has significant antioxidant and antimicrobial activity while plant is devoid of in-vitro anticancer activity against human leukemia cell line HL-60.

Key words: Blepharisrepens, Bioautography, Anti-oxidant, anti-microbial, Anti-cancer, HL-60.

\section{INTRODUCTION}

Blepharis repens (Vahl) Roth of Acanthaceae family is edible herb and commonly known as Hadsan in Marathi and Haridachchu in Kannada. ${ }^{1,2}$ It iscommonly found in rocky regions of Tamil Nadu, Delhi, Chota-nagpur and in Srilanka. The whole plant is of good medicinal value and has been used as folk remedy for treating ailments like wounds, bone fracture, skin disease, urinary infections, cancer, diarrhea and leaves are useful in syphilis and dysentery. ${ }^{3-6}$ Traditionally whole plant powder with milk and or wheat or black gram floor is commonly used in healing bone fracture in various parts of India. Tribal people in southern India uses leaf juice heated in gingelly oil topically for wound healing. ${ }^{7,8}$ Very little information for both phytochemistry and pharmacological efficacy is available on this plant. ${ }^{9}$ Pharmacologically, all parts of plant have been reported to possess antidiabetic, antihyperlipidaemic, hepatoprotective and bone and wound healing activity. ${ }^{10}$

The objective of the present study is to establish pharmacognostic and in-vitro biological like antioxidant, anticancer, antimicrobial efficacy parameters. The results will be helpful in identification, preventing possible adulteration and primary evaluation as part of primary stage of quality control standardization of herbal drugs.

\section{MATERIALS AND METHODS}

Plant material collection, identification and authentication

Plant material was collected from surrounding open field in hill, rocky region in district Hingoli taluka Sengaon. Identification and authentication was done by Dr. Arvind S. Dhabe, Professor, Department of Botany, Dr. Babasaheb Ambedkar Marathwada University, Aurangabad. (Accession number is 0564).

\section{Plant material extraction}

The plant was shade dried for 7 days and cleaned, introduced in cutter mill and powder is obtained. This powder is stored in air tight container. From that $100 \mathrm{gm}$ of powder wrapped in thimble which isexhaustively extractedusing petroleum ether, chloroform, methanol, water and hydro-alcohol $(70 \%)$ as solvent in successive solvent extractor. Extraction continues till the solvent in sample tube became clear at required temperature to particular solvent. The extract was obtained which subjected to 
concentrate to one fourth volume under reduced pressure for further use wherever required. ${ }^{11}$

\section{Pharmacognostic evaluation}

\section{Morphological, microscopical and powder microscopical evaluation}

Morphological evaluation of various parts of plant like root, leaf, stem and flower was performed. Colour, odour, taste, shape is evaluated by visual observation and size is measured for width and length. For microscopical evalaution, stem, root and leaf were kept in water for some time and sections were taken with the help of blade. The sections were hydrated with glycerin and covered with cover slip and focused under digital microscope. Photographs under normal bright field at different magnifications were taken. Similarly, powder was evaluated for different microscopic parameters. ${ }^{12}$

\section{Physicochemical evaluation}

The determination of various physicochemical constants such as ash values, extractive values, element detection and loss on drying determined as per World Health Organization guidelines. All experiments were carried out in triplicates and expressed as mean value. ${ }^{12-14}$

\section{Fluorescence analysis of powder drug}

Powdered plant material was treated with various chemical reagents and exposed to visible, ultraviolet light (Short UV) to explore their fluorescence behavior. A small amount of powder drug was placed on a micro slide and treated with $1 \mathrm{~N} \mathrm{NaOH}$ in methanol, $1 \mathrm{~N} \mathrm{HCl}, 1 \mathrm{~N}$ $\mathrm{NaOH}$ in water, nitric acid (1:1), sulphuric acid (1:1), glacial acetic acid, $1 \mathrm{~N}$ potassium hydroxide and observed under UV $366 \mathrm{~nm}$, UV $254 \mathrm{~nm}$ and in daylight under moist condition. ${ }^{15,16}$

\section{Phytochemical evaluation}

\section{Preliminary phytochemical screening}

Preliminary phytochemical screening of pure extract for various class of phyto-constituent such as alkaloid, glycoside, tannin, carbohydrate, saponin, protein, flavonoids, steroids, gum, mucilage and oil is completed by chemical evaluation using various reagents. ${ }^{13}$ The osazone test for carbohydrate lead to formation of various shapes of crystals. Cube shape crystals may be of glucose or fructose, needle shape may be of monosaccharides and flower shape crystal may be of maltose sugar.

\section{Quantitative estimation of phytochemicals}

Various phytochemicals present in the hydro-alcoholic (70\%) extract were quantified for total carbohydrate content by anthrone method, total tannin content by Folin-Denis method, total flavonoid content by aluminium chloride method, total alkaloid content by BromocresolGreen method using glucose, tannic acid, quercetin and atropine as standard drug respectively. ${ }^{13}$

\section{Thin layer chromatography analysis}

TLC separation and evaluation for different phytoconstituent of four extracts is carried out using silica gel GF254 as stationary phase and different mobile phases as well as spraying reagents as summarised in Tables $1-5 \cdot{ }^{13,17}$ Extracts are dissolved in their respective solvents and then spots are applied by using microcapillary on TLC plates.

\section{In-vitro biological activity}

In vitro antioxidant activity by 2, 2-Diphenyl-1-picrylhydrazyl (DPPH) radical-scavenging method

$1 \mathrm{ml}$ of different concentration of extract solution was taken in different

\section{Table 1: Physicochemical standard values for B.repens.}

\begin{tabular}{ccc}
\hline No & Parameters Evaluated & Values \\
\hline $\mathbf{1}$ & Ash values \\
& Total ash value & $13.85 \%$ \\
& Water soluble ash value & $3.1 \%$ \\
& Acid insoluble ash value & $7.7 \%$ \\
\hline $\mathbf{2}$ & Extractive value & \\
& Petroleum ether & $0.84 \%$ \\
& Alcohol & $1.64 \%$ \\
& Water & $3.52 \%$ \\
\hline
\end{tabular}

Table 2: Elements detection.

\begin{tabular}{ccc}
\hline No & Test & Inference \\
\hline 1 & Calcium & + \\
2 & Magnesium & - \\
3 & Sodium & - \\
4 & Potassium & - \\
5 & Iron & - \\
6 & Sulphate & + \\
7 & Phosphate & - \\
8 & Chloride & - \\
9 & Carbonate & - \\
10 & Nitrogen & + \\
\hline
\end{tabular}

Where +: Present and -: Absent

Table 3: Preliminary Phytochemical investigation of B.repens.

\begin{tabular}{cccc}
\hline Sr. No. & Test & Inference & \\
\hline 1 & Carbohydrates & + & + \\
2 & Proteins & - & - \\
3 & Alkaloids & + & + \\
4 & Cardiac Glycoside & - & - \\
5 & Anthraquinone Glycoside & - & - \\
6 & Cynogenetic Glycoside & - & - \\
7 & Coumarin Glycoside & - & - \\
8 & Flavonoids & + & + \\
9 & Tannins & + & + \\
10 & Steroid or Triterpenoid & - & - \\
11 & Saponin & + & + \\
12 & Gum & - & - \\
13 & Mucilage & - & - \\
14 & Fatty Oil & - & - \\
15 & Essential Oil & - & - \\
\hline
\end{tabular}

where + Present and - Absent

Table 4: Powder drug analysis of B.repens with different chemicals.

\begin{tabular}{|c|c|c|c|c|}
\hline No & Test & Daylight & UV $366 \mathrm{~nm}$ & UV $254 \mathrm{~nm}$ \\
\hline 1 & Powder $+1 \mathrm{~N} \mathrm{NaOH}$ in water & Green & $\begin{array}{c}\text { Fluorescence } \\
\text { Green }\end{array}$ & Herbal green \\
\hline 2 & Powder $+1 \mathrm{~N} \mathrm{HCl}$ & Cream & Cream & Cream \\
\hline 3 & $\begin{array}{l}\text { Powder }+1 \mathrm{~N} \mathrm{NaOH} \text { in } \\
\text { methanol }\end{array}$ & Brown & Brown & $\begin{array}{c}\text { Fluorescence } \\
\text { green }\end{array}$ \\
\hline 4 & Powder + HNO3 (1:1) & Orange & Orange & Orange \\
\hline 5 & Powder + H2SO4 (1:1) & $\begin{array}{l}\text { Greenish } \\
\text { black }\end{array}$ & Green & Dark green \\
\hline 6 & Powder + glacial acetic acid & $\begin{array}{l}\text { Green } \\
\text { (henna) }\end{array}$ & Green & Grayish green \\
\hline 7 & Powder + $1 \mathrm{~N} \mathrm{KOH}$ & Brown & Brown & $\begin{array}{c}\text { Fluroscence } \\
\text { brown }\end{array}$ \\
\hline
\end{tabular}


Table 5: TLC profile of extracts for different phytochemical classes.

\begin{tabular}{|c|c|c|c|c|c|}
\hline Phytochemical & \multicolumn{2}{|c|}{ Mobile phase: } & \multicolumn{3}{|c|}{ Detection } \\
\hline Carbohydrate & \multicolumn{2}{|c|}{ Ethyl acetate: toluene (1:3) } & \multicolumn{3}{|c|}{$\begin{array}{c}10 \% \text { ethanolic sulphuric acid Treatment after spraying: heated on hot plate at } 110^{\circ} \mathrm{C} \text { till color } \\
\text { developed and intensified }\end{array}$} \\
\hline Alkaloid & \multicolumn{2}{|c|}{$\begin{array}{l}\text { Methanol: Toluene: Dioxane: Ammonia } \\
\text { (4:2:5:1) }\end{array}$} & \multicolumn{3}{|c|}{ Dragendroff's reagent } \\
\hline Saponin & \multicolumn{2}{|c|}{$\begin{array}{l}\text { Chloroform: Glacial acetic acid: Formic } \\
\text { acid: Water (16:8:3:2) }\end{array}$} & \multicolumn{3}{|c|}{$\begin{array}{c}\text { Vanillin sulphuric acid. Treatment after spraying: heated on hot plate at } 110^{\circ} \mathrm{C} \text { till color } \\
\text { developed and intensified }\end{array}$} \\
\hline Flavanoid & \multicolumn{2}{|c|}{$\begin{array}{l}\text { Ethyl acetate: Formic acid: glacial acetic } \\
\text { acid: Water }(20: 2.2: 2.2: 5.2)\end{array}$} & \multicolumn{3}{|c|}{$\begin{array}{c}\mathrm{AlCl}_{3} \text { Reagent Treatment after spraying: heated on hot plate at } 110^{\circ} \mathrm{C} \text { till color developed and } \\
\text { intensified }\end{array}$} \\
\hline Tannin & \multicolumn{2}{|c|}{$\begin{array}{l}\text { Ethyl acetate: acetic acid: Formic acid: } \\
\text { Water (14: 0.4: 0.6:4) }\end{array}$} & \multicolumn{3}{|c|}{$\begin{array}{c}\text { Anisaldehyde sulphuric acid Treatment after spraying: heated on hot plate at } 110^{\circ} \mathrm{C} \text { till color } \\
\text { developed and intensified. }\end{array}$} \\
\hline Sr.No & hytochemical class & Extra & act & Colour of spot & Rf value \\
\hline \multirow[t]{3}{*}{1} & \multirow[t]{3}{*}{ Carbohydrate } & \multicolumn{2}{|c|}{ Aqueous extract } & Violet & 0.56 \\
\hline & & \multicolumn{2}{|c|}{ Methanolic extract } & Violet, yellowish green & $0.56,0.88$ \\
\hline & & \multicolumn{2}{|c|}{ Chloroform extract } & Violet & 0.56 \\
\hline 2 & Alkaloid & \multicolumn{2}{|c|}{ Methanolic extract } & Orange & 0.87 \\
\hline 3 & Tannin & \multicolumn{2}{|c|}{ Chloroform extract } & Brown & 0.76 \\
\hline 4 & Saponin & \multicolumn{2}{|c|}{ Methanolic extract } & Violet, Yellow, Light yellow & $0.53,0.68,0.77$ \\
\hline 5 & Flavonoid & \multicolumn{2}{|c|}{ Methanolic extract } & B Brown & 0.76 \\
\hline
\end{tabular}

test tubes. To this $5 \mathrm{ml}$ of methanolic solution of DPPH was added, shaken well and covered with aluminium foil, mixture was incubated at $37^{\circ} \mathrm{C}$ for $30 \mathrm{~min}$. The absorbance was measured against methanol as blank at $517 \mathrm{~nm}$. Absorbance of DPPH solution was taken as control. Percent scavenging activity was calculated by formula: Scavenging activity $(\%)=$ absorbance control- absorbance sample / absorbance control $\times 100$. IC50 values were determined from the graphs of percentage scavenging activity against concentration of extracts. These values are defined as inhibitory concentration of the extract necessary to decrease the initial DPPH radical concentration by $50 \%$ and are expressed in $\mu \mathrm{g} / \mathrm{ml}^{18-21}$

\section{In-vitro anticancer activity by SRB assay method}

The monolayer cell culture was trypsinized and the cell count was adjusted to $0.5-1.0 \times 10^{5}$ cells $/ \mathrm{ml}$ using medium containing $10 \%$ new born sheep serum. To each well of the 96 well microtitre plate, $0.1 \mathrm{ml}$ of the diluted cell suspension (approximately 10,000 cells) was added. After 24 hours, when a partial monolayer was formed, the supernatant was flicked off, washed once and $100 \mu$ of different test compound concentrations were added to the cells in micro titre plates. The plates were then incubated at $37^{\circ} \mathrm{C}$ for 72 hours in $5 \% \mathrm{CO}_{2}$ incubator, microscopic examination was carried out, and observations recorded every 24 hours. After 72 hours, $25 \mu$ of $50 \%$ trichloro acetic acid was added to the wells gently such that it forms a thin layer over the test compounds to form overall concentration $10 \%$. The plates were incubated at $4^{\circ} \mathrm{C}$ for one hour. The plates were flicked and washed five times with tap water to remove traces of medium, sample and serum, and were then air-dried. The air-dried plates were stained with $100 \mu l$ $\mathrm{SRB}$ and kept for 30 minutes at room temperature. The unbound dye was removed by rapidly washing four times with $1 \%$ acetic acid. The plates were then air dried. $100 \mu \mathrm{l}$ of $10 \mathrm{mM}$ Tris base was then added to the wells to solubilize the dye. The plates were shaken vigorously for 5 minutes. The absorbance was measured using microplate reader at a wavelength of $540 \mathrm{~nm}$. The percentage growth inhibition was calculated using following formula, \% cell inhibition $=100-\{(\mathrm{At}-\mathrm{Ab}) /(\mathrm{Ac}-\mathrm{Ab})\}$ $\mathrm{x} 100.22,23$

\section{In-vitro antimicrobial activity by well diffusion method}

In this method the extract diffused from well on solidified agar plate which extend such that growth of added microorganism is preventedin circular area known as zone of inhibition.Using pipette $0.2 \mathrm{ml}$ of each of the seeded broth containing $10^{6}-10^{7} \mathrm{cfu} / \mathrm{ml}$ was inoculated on the plate of solidified agar and speeded uniformly by glass spreader. Then five well cut out in plate by using borer of diameter $5 \mathrm{~mm}$. to the five well the $0.2 \mathrm{ml}$ solution of four extract and standard was added to each well. all work carried out under aseptic condition. This plate is incubated at $37^{\circ} \mathrm{C} \pm 1^{\circ} \mathrm{C}$ for 24 hours. After incubation period diameter of the zone of inhibition in mm obtained around the well was measured. ${ }^{24-26}$

\section{In vitro antimicrobial activity by bioautographic method}

Different constituents of petroleum ether, chloroform, methanol and water extracts based on polarity were separated by TLC using silica gel GF254 as stationary phase. Benzene: ethanol: ammonia hydroxide (18:2:0.2) for non-polar constituents, chloroform: ethyl acetate: formic acid (5:4:1) for intermediate polar and ethyl acetate: methanol: water (40:5.4:5) for polar constituents were used as mobile phases. Bacterial culture suspended nutrient agar media is prepared and over-layed on the $48 \mathrm{hr}$. old developed TLC plates and allowed to solidify. Then plates kept in chamber and covered with lid. This overlay plate is incubated at $37^{\circ} \mathrm{C} \pm 1^{\circ} \mathrm{C}$ for 24 hours. Band of inhibition is observed. Further the plates sprayed with INT dye and incubated for $24 \mathrm{hr}$. Finally growth of inhibition is visualized as yellow band on violet background. ${ }^{27,28}$

\section{RESULTS AND DISCUSSIONS}

Pharmacognostic standardization helps for correct identification, authentication and detection of adulteration and routine quality control of crude drugs. Physicochemical numerical standards reported in this work will be useful for correct identification, doubtful specimen evaluation and compilation of a suitable monograph.

Morphological evaluation explores that fresh stem is cylindrical, brown, covered with multicelluar covering tichomes and 7.5-15 cm long. Leaf is green, has symmetric base, entire margin, acute apex, oblong shape, $1.25-3 \mathrm{~cm}$ long and $0.5-1 \mathrm{~cm}$ wide. Roots are cylindrical, round, long branched, $7-10 \mathrm{~cm}$ long and $3-5 \mathrm{~mm}$ wide. (Figure1). Whole plant is having characteristic odor and taste.

Microscopical characteristics of stem of B.repens shows many layered (2-3) thin walled rounded shape cortex, multicellular uniseriate covering trichomes, single layered epidermis, xylem, phloem, thin 
layered pericyclic fibres above vascular bundle. (Figure1) Microscopy of leaf shows two subsidiary cell at right angle to stoma. Hence it is cross- celled or diacytic or caryophyllus stomata. Leaf shows isobilateral lamina, unicellular trichomes, thick walled covering to vascular bundle, sclerenchymatous sheath, single layer upper epidermis, multilayered elongated and compact palisade cells, non lignified phloems, lignified xylems, multilayer loosly arranged parechymatous cells as shown in figure 1. Root of B.repens shows thin walled many layered packed elongated cortex, 2-3 layered tangentially, elongated thin walled phelloderm, brown colour multi-layered elongated cork cells, xylem and phloem as shown figure 1. Microscopical examination powder of whole herb of B.repens shows pitted xylem vessels, sclerenchymatous fibres, parenchymatous cells, phloem fibres, multicellular uniseriate covering trichomes as shown in figure1.

Total ash value, water soluble ash value and acid insoluble ash values are determined and found $13.85 \%, 3.1 \%, 7.7 \%$ respectively. Results reveals that plant contain significant amount of total ash and acid insoluble ash. Ash values are indication of total inorganic composition of plant drugs and particularly important in the evaluation of safety and toxicity of drugs.

Extractive values comparison confirms that plant contain more polar constituents than semi-polar and non-polar constituents as shown in Table 1. Element detection reveals that the whole plant contains calcium, sulphate, nitrogen and other elements are absent as shown in Table 2.

Preliminary phytochemical screening reveals the presence of various types of phytoconstituents like carbohydrates, alkaloids, saponins, flavonoids, tannins in B.repens. (Table 3) Whereas primary metabolites like protein, gum, mucilage, fatty oil and secondary metabolites like glycosides, steroids and essential oil components seems to be absent. Preliminary phytochemical screening gives idea about the qualitative nature of active phytoconstituent present in the alcoholic and aqueous extract of whole plant of B.repens.

Table 4 summarised results of the fluorescence analysis of B.repens powder under day light as well as long and short UV light $(365 \mathrm{~nm}$ and $254 \mathrm{~nm}$ ) after treatment with different chemicals .

Estimation of phytoconstituents in the extract (70\% alcohol) is an important step prior conducting any isolation of active biochemical marker/s as it gives idea about the separable quantity of active phytoconstituents present in plant extract. From the quantitative estimation, it is observed that extract contain maximum content of carbohydrates and tannin. The estimated values are carbohydrate 5.78\%; tannin $5.7 \%$, flavonoid $1.48 \%$, and alkaloid $1.43 \%$ were quantified by colorimetric methods (Table 5).

Thin layer chromatography (Figure 2) confirmed presence of carbohydrates in aqueous, methanol, chloroform extracts among four extract at Rf 0.56 . While presence of alkaloids observed only in methanol extract at Rf 0.87 and presence of tannins or polyphenols is observed only in chloroform extract at Rf 0.76 . Saponins are confirmed only in methanolic extract having colour violet, yellow, light yellow at Rf $0.53,0.68,0.77$ respectively and flavonoid observed at Rf 0.76 .

In vitro antioxidant by DPPH (Table 6) reveals that both methanolic and aqueous extracts of B.repens possess significant free radical scavenging properties in concentration-dependent manner. Hence, it can be concluded that the B.repens could be further pharmaceutically exploited for antioxidant properties by in vivo models. Methanolic extract showed more potent antioxidant activity than aqueous extract which might be due to presence of polyphenolic compound and flavonoids.

In vitro anticancer activity of four extracts and alkaloid fraction of B.repens is performed on HL 60 cancer cell lines at ACTREC Mumbai, India. The cell viability was measured using SRB assay. As IC50 values of all extracts found above $80 \mu \mathrm{g} / \mathrm{ml}$, hence it is concluded that evaluated extracts of B.repens do not have anticancer potential against selected leukemia cell line. Finally, it can be concluded that extracts of B. repens have strong antioxidant activity but no anticancer activity against human leukemia cell line HL-60.

Antimicrobial activity study of methanolic, chloroform, petroleum ether extract and alkaloid fraction has shown maximum activity against $S$. aureus, medium potency for $E$. coli and very weak activity against $A$. niger. Aqueous extract showed weak activity against E.coli and S.aureu (Figure 3). All four extracts like petroleum ether, chloroform, methanol, aqueous shows potency against strain Eschericha coli, Aspergillus niger, Staphylococcus aureus. Chlorofom and methanolic extract showed strong antimicrobial activity against Eschericha coli and Staphylococcus aureus while weak activity against Aspergillus niger. Bioautographic method results revealed antimicrobial potency of chloroform and methanolic extract due to presence of saponins.

Phytochemical screening by TLC revealed the presence of varied chemical components like carbohydrates, tannins, polyphenols, saponins and alkaloids in the different extracts of the plants. This is notable from the different colour changes depicted by individual

\section{Table 6: \% Scavenging activity of different extract by DPPH method.}

\begin{tabular}{|c|c|c|c|c|}
\hline Sr.no & Conc $(\mu \mathrm{g} / \mathrm{ml})$ & Absorbance & IC50 & \% Scavenging activity \\
\hline \multicolumn{5}{|c|}{ Control Abs $=0.5231$} \\
\hline \multirow[t]{5}{*}{1} & Ascorbic acid & & & \\
\hline & 100 & $0.0190 \pm 0.0001$ & & 96.36 \\
\hline & 250 & $0.0214 \pm 0.0005$ & & 95.90 \\
\hline & 500 & $0.0243 \pm 0.0004$ & 15564.33 & 95.35 \\
\hline & 1000 & $0.0331 \pm 0.0006$ & & 93.67 \\
\hline \multirow[t]{5}{*}{2} & Methanolic & & & \\
\hline & 100 & $0.1504 \pm 0.0006$ & & 71.24 \\
\hline & 250 & $0.2050 \pm 0.0004$ & & 60.81 \\
\hline & 500 & $0.2778 \pm 0.0002$ & 433.44 & 46.89 \\
\hline & 1000 & $0.4517 \pm 0.0002$ & & 13.64 \\
\hline \multirow[t]{5}{*}{3} & Aqueous & & & \\
\hline & 100 & $0.2290 \pm 0.0004$ & & 56.22 \\
\hline & 250 & $0.2789 \pm 0.0003$ & & 46.68 \\
\hline & 500 & $0.3799 \pm 0.0003$ & 161.450 & 27.37 \\
\hline & 1000 & $0.4449 \pm 0.0002$ & & 14.94 \\
\hline
\end{tabular}




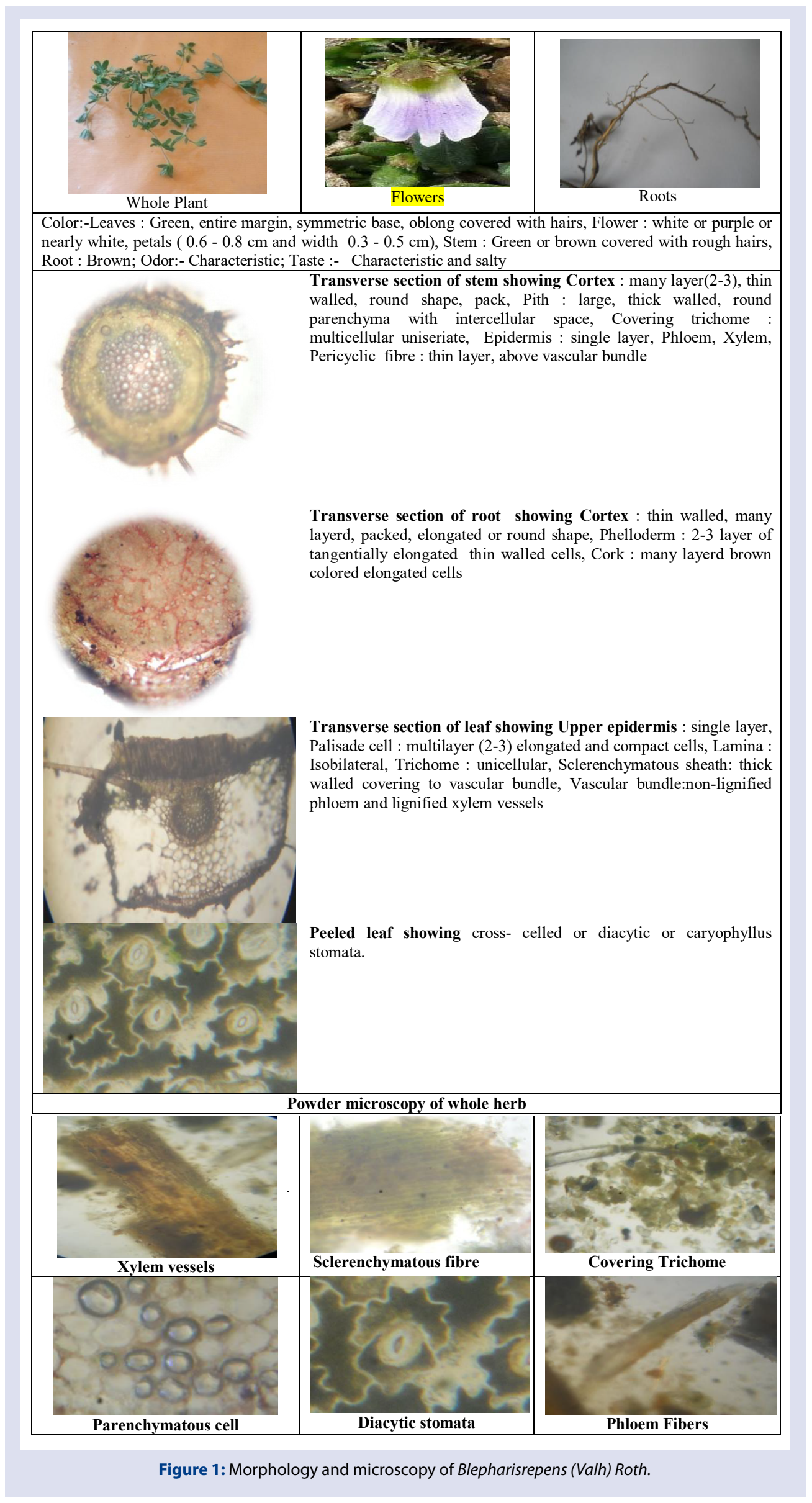


Table 7: \% control growth of Human leukemia cell line.

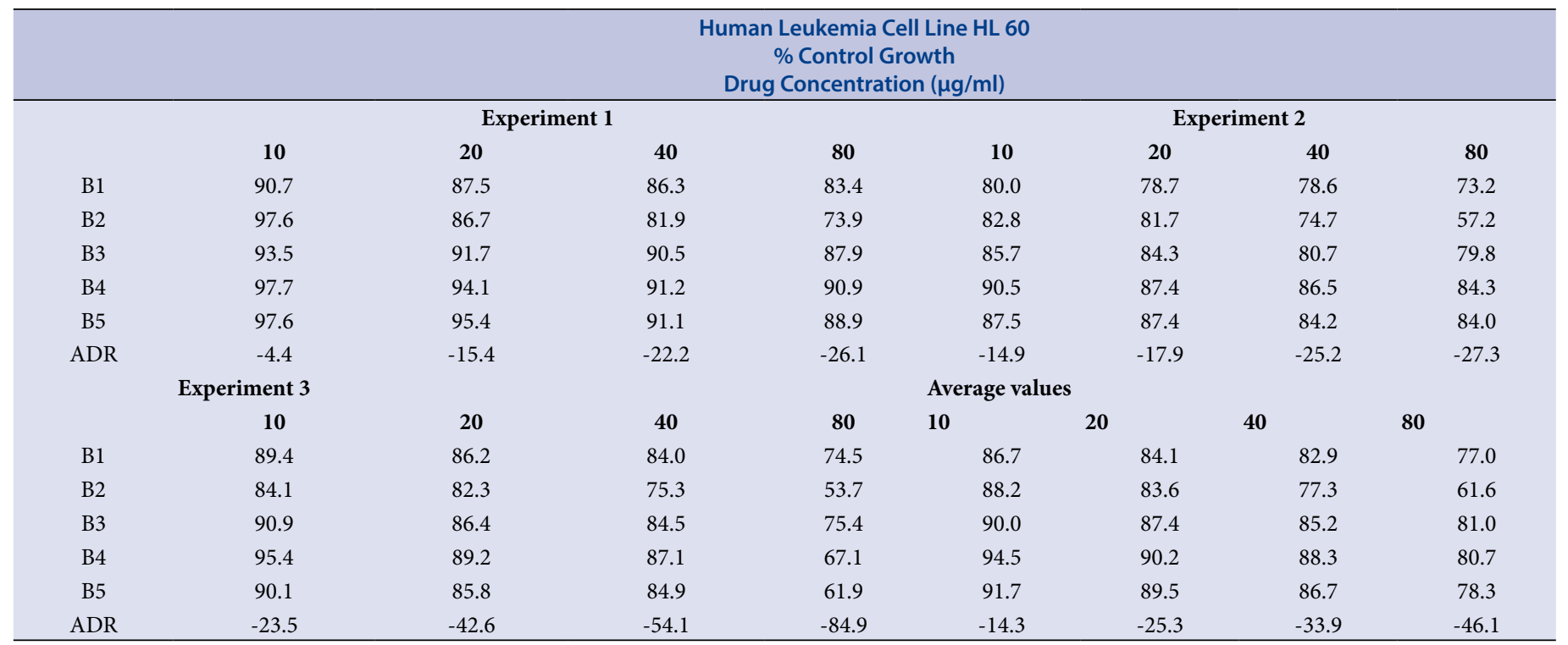

Where B1 Aqueous extract, B2 Methanol extract, B3 Chloroform extract, B4 Petroleum ether extract, B5 alkaloid fraction.
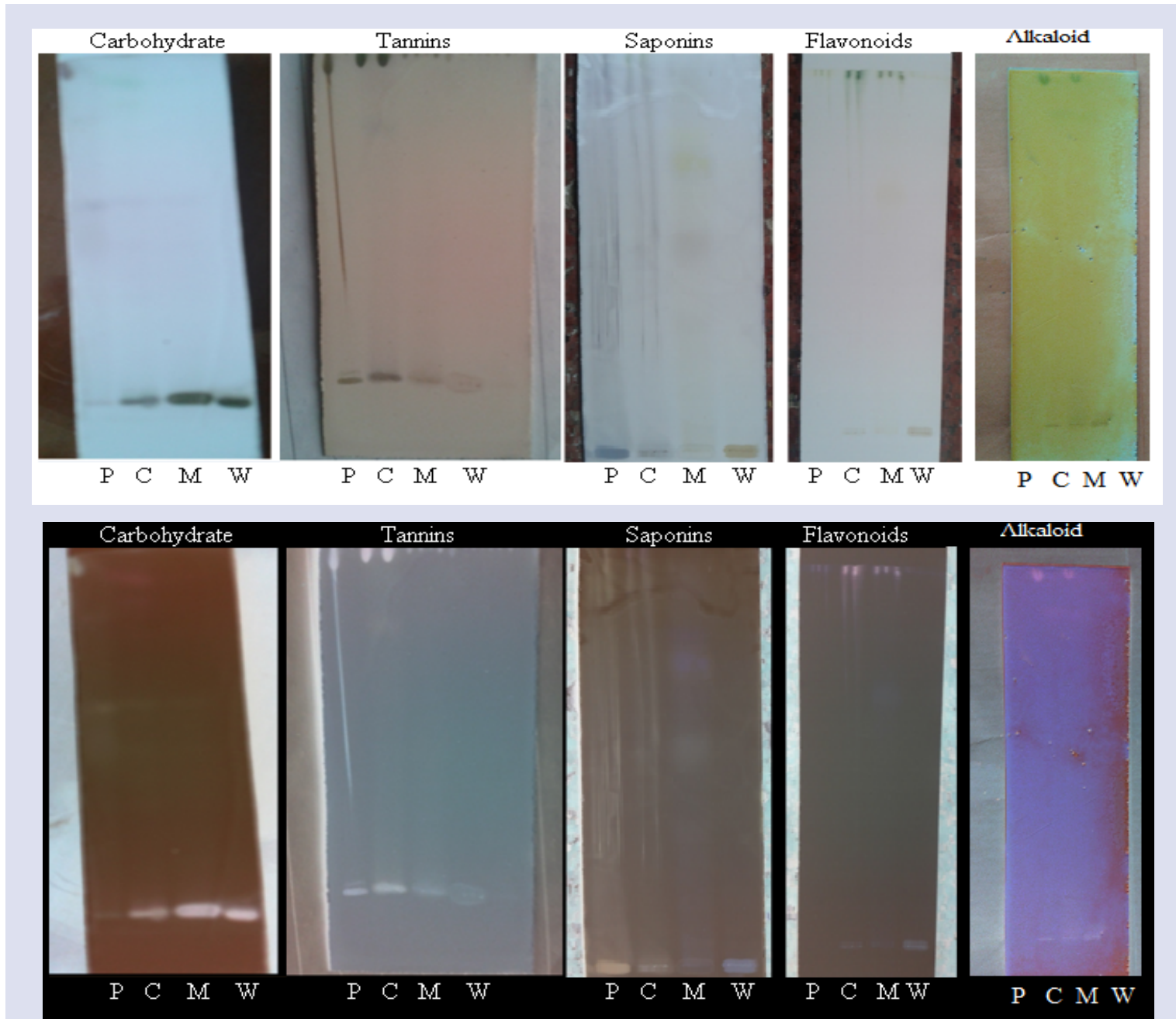

Figure 2: TLC of different phytochemical [P: Pet ether extract; C: Chloroform extract; M: Methanolic extract; W: Aqueous extract]. 

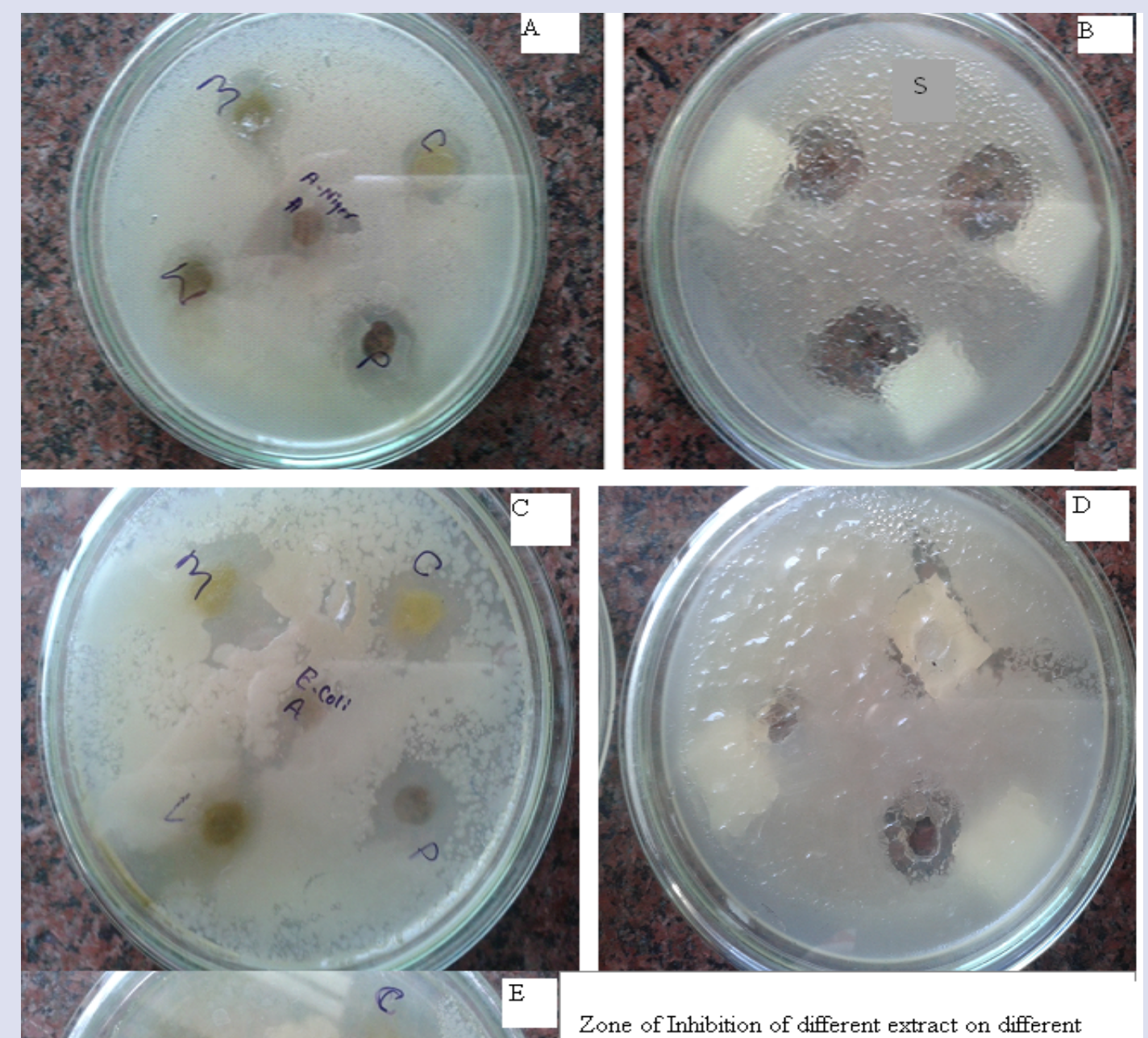

Zone of Inhibition of different extract on different test organism (mm)

\begin{tabular}{|l|l|l|l|l|}
\hline No & Strain & $\begin{array}{l}\text { S. } \\
\text { aureus }\end{array}$ & $\begin{array}{l}\text { E. } \\
\text { coli }\end{array}$ & $\begin{array}{l}\text { A. } \\
\text { niger }\end{array}$ \\
\hline 1 & Aqueous & - & 7 & 6 \\
\hline 2 & Methanol & 12 & 8 & 10 \\
\hline 3 & Chl oroform & 10 & 12 & 8 \\
\hline 4 & Pet ether & 9 & 10 & 9 \\
\hline 5 & Standard & 15 & 14 & 17 \\
\hline
\end{tabular}

Figure 3: Antimicrobial activity by Agar-well diffusion method.

compounds due to their reaction with the spray reagent used (vanillin/ sulphuric acid). In bioautographic method, the appearance of white areas against a purple-red background on the chromatograms denotes inhibition of growth of the bacteria or fungi (Figure 4) due to presence of compound that inhibit their growth. Actively growing microorganisms have the ability to reduce INT to a purple-red colour. In the presence of active plant compounds on the chromatograms, the growth of the organism is inhibited. Most of the antimicrobial agents detected in this study were present in extracts of relatively semi-polar solvents. Comparison of developed TLC before and after bioautography reveals that antimicrobial compounds are saponins. Plate A developed in mobile phase 2 shows band of inhibition on Rf 0.22 in both Chloroform and methanolic extract spot. Plate B developed in mobile phase 1 shows band of inhibition on Rf 0.317 and Rf 0.258 in Chloroform and methanolic extract spot (for S.aureous) Plate C developed in mobile phase 2 shows band of inhibition on Rf 0.9 in Chloroform extract. Thus in bioautography, it can be concluded that chloroform and methanol extract have presence of phytochemicals (saponins probably) responsible for antibacterial activity against E.coli and S. aureous. Pet. ether, aqueous, alcoholic extracts and isolated alkaloid have not shown antimicrobial activity in bioautography. But results of agar well diffusion and bioautography method shows that it might possible that all phytochemicals present in extracts have combine effect against Aspergillus niger, Staphylococcus pyroginus and Candida albicans hence antimicrobial potency found in agar-well diffusion method but not in bioautography. 

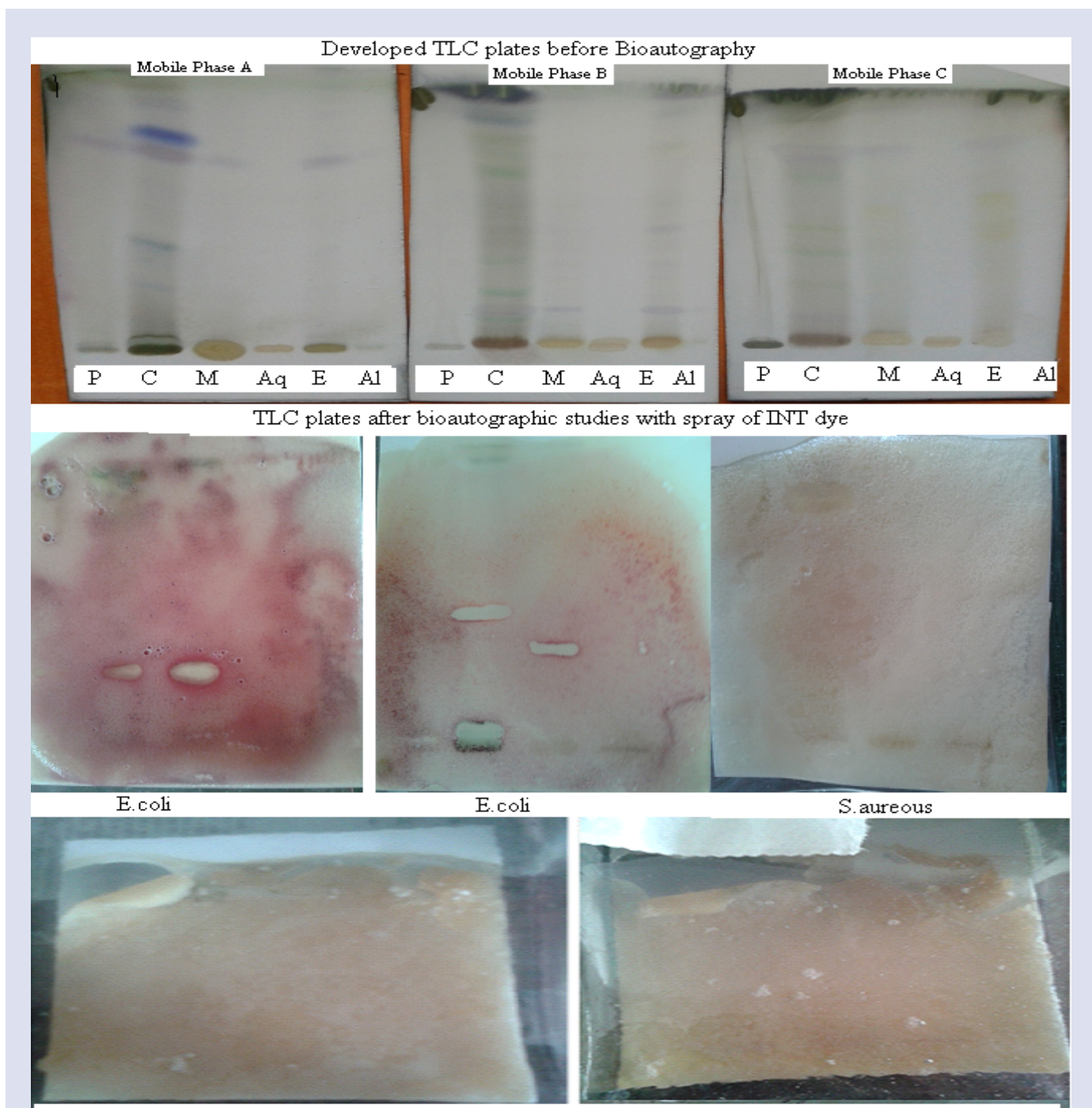

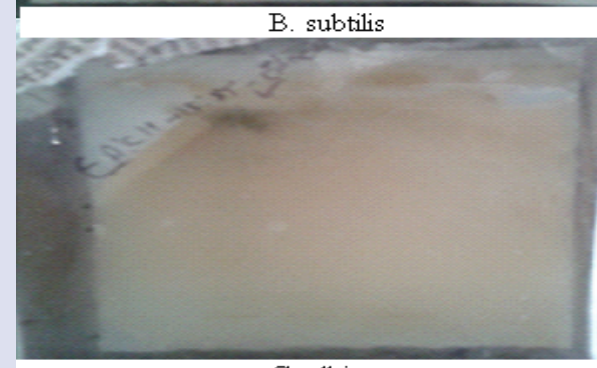

C. albicans
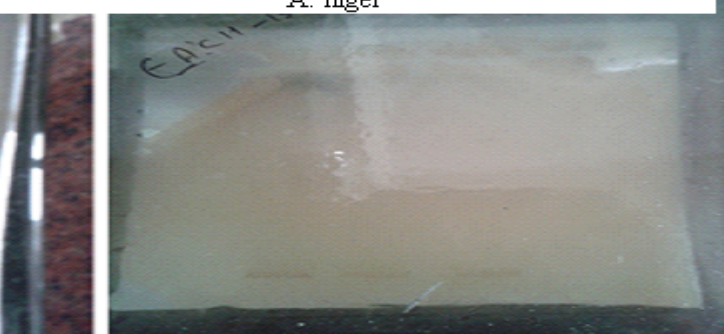

S. pyrogens

Figure 4: Bioautographic antimicrobial potential of different extracts of B.repens P: Pet ether extract, C: chloroform extract, M: methanolic extract, Aq: aqueous extract, E: Ethanolic extract, Al: isolated alkaloid.

\section{CONCLUSION}

Folk claim of use of $B$. repens in wound healing along with secondary skin infections, skin and urinary infections, diabetes and cancer can be explored scientifically with present paper results. Antimicrobial and anti-oxidant potential is responsible for wound healing along with associated secondary infections, skin and urinary infections. Antioxidant potential is also responsible for treatment of cancer and diabetes. In present paper, $B$. repens extracts are not found anticancer against leukemia cell lines but same extracts might be useful against other cancer cell lines. Finally it can be concluded that morphological, microscopical, physicochemical, chemical and few biological parameters like antioxidant, anticancer, antimicrobial efficacy of plant B.repens established for the first time.

\section{CONFLICTS OF INTEREST}

The authors declare no conflicts of interest.

\section{REFERENCES}

1. Ayyanar M, Ignacimuthu S. Herbal medicine for wound healing among tribal people in southern India: Ethnobotanical and Scientific evidences. International Journal of Applied Research in Natural Product. 2009;2(3):29-39.

2. S.S.Hebbar, V.H.Harsha, V.Shripathi, G.R.Hegde. Ethnomedicine of Dharwad in Karnataka, India-plant use in oral health care. Journal of Ethnopharmacology 2004;94:261-6

3. Ramya Subramanian, Gopinath Krishnasamy, Aruna Devaraj, Padma vaathy Sethuraman, Ramaraj Jaukumararaj. Wounds healing ethanopharmacological potentials of selected medicinal plants used by malayali tribes. International Research Journal of Pharmacy. 2011;2(5):132-7. 
4. M.Z.Chopda, R.T.Mahajan. Wound Healing Plants of Jalgaon District of Maharashtra State, India. Ethnobotanical Leaflets. 2009;13:1-32.

5. Dushing YA, Patil DA. Ethnomedicine in Buldhana District of Maharashtra (India). Journal of Phytology. 2010;2(12):43.

6. Kulkarni CG, Adwait, Deshpande. Folk therapies of Katkaris from Maharashtra. Indian Journal of Traditional knowledge. 2011;3:554-8.

7.Pawar Shubhangi and DA. Patil. Ethnomedicinal plants in Jalgaon District. Current Botany. 2011;2:4

8. Borkar SU, Korpenwar AN, Patil, RB Patil. Documentation of Ethno-veterinary practices used by tribals in Yavatmal district, (M.S) India. Bionanofrontie. 2012;5(2):250-1.

9. M. Rajan, N. Senthil Kumar, G. Jeyabalan. Evaluation of pharmacognostical, preliminary phytochemical studies on B.repens (Valh)Roth. International Journal of Phytotherapy. 2013;3:82-90.

10. Rajan M, N.Senthilkumar, G.Jeyabalan. Antidiabetic, antihyperlipidaemic and hepatoprotective activity of whole plant ethanolic extract of blepharis repens (vahl) roth in normal and alloxan induced diabetic rats. International Journal of Biological \& Pharmaceutical Research. 2013;4(11):802-8.

11. C. K. Kokate, A. P. Purohit, S. B. Gokhale. Pharmacognosy, Nirali Prakashan, Pune; 39th Edition; 2007.

12. K. R. Khandelwal. Practical Pharmacognosy, Nirali Prakashan, Pune 2008:52 70,134, 123-127,155-156.

13. SS. Khadabadi, SL. Deore, BA. Baviskar. Experimental Phytopharmacognosy, Nirali Prakashan, Pune, 2011:3:1-3.8., 4.2-4.38, A2.1-A2.2.

14. World Health Organization. Quality control methods for medicinal plant materials, WHO/PHARM/92.559, 1998; 4-46.

15. Deependra Soni, Anshita Gupta, Rashmi Solanki, Goutam Kumar Jana Pharmacognostical, phytochemical and physiochemical findings over the root extract of Hibiscus rosasinesis[Malvacae]. Journal of Natural Product Plant Resources. 2011;1(4):73-9.

16. Prakash Chandra Gupta, Nisha Sharma, Ch V Rao,. Pharmacognostic study of leaves and stem Careyaarborea Robx. Asian Pac J Trop Biomed. 2012;2(5):404-8.

17. Hilde BertWagnar Sagin Bladt. Plant Drug Analysis -A thin layer Chromatography Atlas Second edition: 166.
18. Jakus $\mathrm{V}$. The role of free radical, oxidative stress and antioxidant system in diabetes vascular disease. British Lek Listy. 2000;101:541-51.

19. Nassim Djabou, Mohamed El Amine Dib, HocineAllali, Andreas Bender, Mohammad A. Kamal, Said Ghalem, Boufeldjaabti. Evaluation of antioxidant and antimicrobial activities of the phenolic composition of Algerian Arbutus unedo L. roots. Pharmacognosy Journal. 2013;5:275-80.

20. Pallauf K, Rivas-Gonzalo JC, Del Castillo MD, Cano MP, De Pascual-Teresa SJ. Characterization of the antioxidant composition of strawberry tree (Arbutus unedo L.) fruits. Food Compos Anal. 2008;21:273-81.

21. Mohaddese Mahboubi, Ghasem Haghi, Nastaran Kazempour, Ali Reza Hatemi, Total phenolic content, antioxidant and antimicrobial activities of Blepharis edulis extracts, Songklanakarin. J Sci Technol. 2013;35(1):11-6.

22. SN Gaidhani, GS Lavekar, AS Juvekar, S Sen, Arjun Singh, Suman Kumari. Invitro anticancer activity of standard extracts used in ayurveda. 2009;5:425-9.

23. Peter Houghton, Rui Fang, IsariyaTechatanawat, GlynSteventon, Peter J. Hylands, C.C. Lee. The sulphorhodamine (SRB) assay and other approaches to testing plant extracts and derived compounds for activities related to reputed anticancer activity, Natural Product Research: The Challenges Facing the Modern Researcher. 2007;42(4):377-87.

24. CleidsonValgas; Simone Machado de Souza; Elza F A Smânia; Artur Smânia Jr.Screening methods to determine antibacterial activity of natural products. Brazilian Journal of Microbiology. 2007;38:369-80.

25. Siddharth Vats, Kanupriya Miglani. Synergistic antimicrobial effect of cow urine and azadirachta indica on infectious microbes. IJPSR. 2011;2(7):1781-5.

26. Nostro, M.P. Germanò, V. D’Angelo, A. Marino, M.A. Cannatelli. Extraction methods and bioautography for evaluation of medicinal plant antimicrobial activity. Letters in Applied Microbiology. 200030(5):79-384.

27. Irena M. Choma, Edyta M. Grzelak. Bioautography detection in thin-layer chromatography. Journal of Chromatography A. 2011;12(18):2684-91.

28. M. M. Suleiman, L. J. MeGaw, V. Naidoo and J. N. Eloff. Detection of Antimicrobia compound by bioautography of different extract of leaves of selected south African tree species. African Journal of traditional, Complementary and Alternative Medicine. 2010;7(1):64-78. 


\section{GRAPHICAL ABSTRACT}

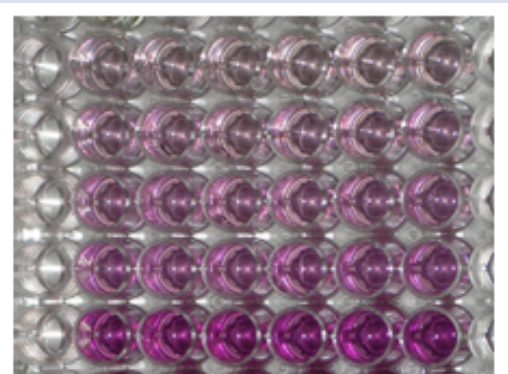

In vitro anticancer activity by SRB Assay-HL-60

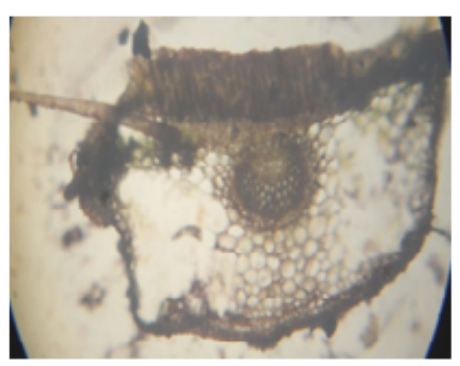

Microscopy

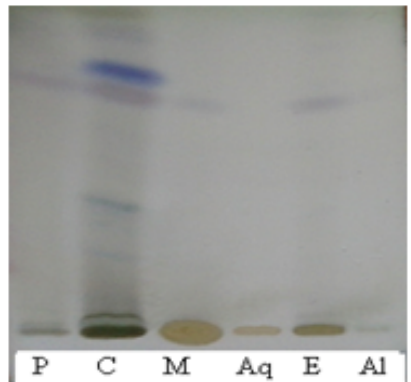

TLC analysis

In vitro anti-oxidant activity DPPH Assay

\section{Blepharis repens (Vahl) Roth}

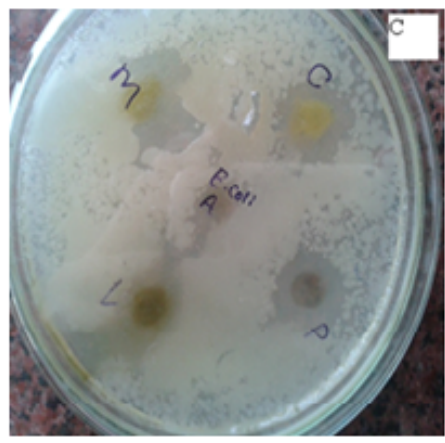

Antimicrobial activity Agar well diffusion method

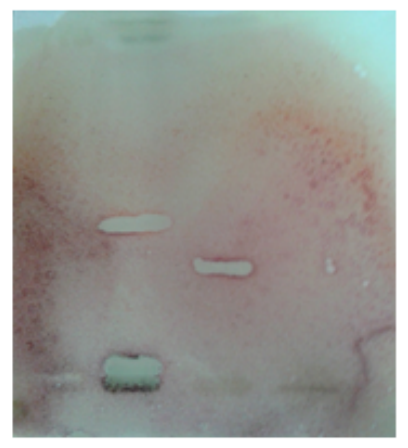

Antimicrobial activity Bioautography

Cite this article: Deore SL, Bhansali PB, Baviskar BA. Pharmacognostic, Phytochemical and In vitro Biological Evaluation of Blepharis repens (Vahl) Roth. Pharmacogn J. 2020;12(5):952-61. 